\title{
PRASANGKA: \\ Potensi Pemicu Konflik Internal Umat Islam
}

\author{
M. Alfandi \\ IAIN Walisongo Semarang \\ e-mail: fandi_iain@yahoo.com
}

\begin{abstract}
This study is about the potential prejudice sparked internal conflict of Muslims, especially between the group Nahdlatul Ulama (NU) and the Council of Tafsir AlQur'an (MTA) in Surakarta. Lately there is a conflict between NU and the MTA congregation. MTA is questioned by NU in some areas because of the materials and methods of preaching/dakwah considered to be provocative and less likely to appreciate the difference fiqhiyah and abusive deeds done by NU. From the reason above, the conflict between these two Islamic organizations appeared. One of the triggers that caused the internal conflict among Muslims is the certain group of Muslims can not understand well the other religious groups, which have different ideological backgrounds; that it affects the way of thinking, behaving and acting that are different from themselves. As a result, the internal relations marred by religious conflict, caused by the internal religious prejudice. Similarly, the possibility that occurred among the group of NU and MTA.
\end{abstract}

$* * *$

Penelitian ini adalah tentang potensi memicu prasangka konflik internal umat Islam, terutama antara kelompok Nahdlatul Ulama (NU) dan Majelis Tafsir AlQur'an (MTA) di Surakarta. Akhir-akhir ini ada konflik antara NU dan jemaat MTA. MTA dipertanyakan/diperdebatkan oleh NU di beberapa daerah karena bahan dan metode dakwah/dakwah dianggap/cenderung provokatif dan cenderung tidak menghargai perbedaan fiqhiyah dengan perbuatan kasar yang dilakukan oleh NU. Dari alasan di atas, konflik antara kedua organisasi Islam telah terjadi/ muncul. Salah satu pemicu yang menyebabkan konflik internal di kalangan umat Islam adalah kelompok tertentu umat Islam tidak bisa memahami dengan baik kelompok agama lain, yang memiliki latar belakang ideologi yang berbeda, sehingga mempengaruhi cara berpikir, bersikap dan bertindak yang berbeda dari diri mereka sendiri. Akibatnya, hubungan internal yang dirusak oleh konflik agama, disebabkan oleh prasangka keagamaan internal. Demikian pula, kemungkinan yang terjadi di antara kelompok NU dan MTA.

Keywords: prasangka, konflik internal, NU, MTA 


\section{A. Pendahuluan}

Agama Islam barangkali merupakan agama yang paling banyak mengalami konflik internal. Sejak masa awal, sepeninggal Nabi Muhammad Saw., konflik dan kekerasan hampir tidak pernah mereda dan menjadi fenomena kesejarahan, serta berlangsung dalam seluruh kurun waktu peradaban. Kepentingan kelompok umat Islam yang dilatarbelakangi oleh ambisi kekuasaan dan perbedaan faham ikut tumbuh dan berkembang, serta dapat memicu terjadinya konflik internal umat Islam. ${ }^{1}$

Islam merupakan agama yang dipeluk mayoritas penduduk di Indonesia. Sebagai agama yang banyak dipeluk oleh penduduknya. Islam tentunya mempunyai peranan penting dalam perjalanan bangsa. Namun, Islam ternyata juga memiliki kemajemukannya sendiri, baik pada karakteristik ajaran, umat dan juga simbol keagamaan. Perbedaan pandangan dalam suatu agama bisa melahirkan konflik di dalam tubuh suatu agama. Perbedaan madzhab adalah suatu perbedaan yang nampak dan nyata. Kemudian lahir pula perbedaan ormas keagamaan. Walaupun satu aqidah yakni aqidah Islam, namun perbedaan sumber penafsiran dan penghayatan, kajian terhadap al-Qur'an dan alSunnah terbukti mampu mendisharmoniskan intern umat Islam.

Dalam kontek masyarakat Muslim, khususnya di Jawa, ada dua kelompok Muslim yang diantara keduanya seringkali terjadi ketegangan, baik dalam bentuk konflik terbuka maupun yang bersifat laten. Kelompok Muslim tersebut adalah kelompok Muslim puritan dan kelompok Muslim kultural. Muslim puritan adalah kelompok Muslim yang menganut faham puritanisme Islam, yaitu suatu faham yang berusaha untuk memurnikan ajaran Islam dari pengaruh luar (termasuk budaya) baik dalam bentuk keyakinan, pemikiran maupun praktik keagamaan. Organisasi yang bercorak puritan misalnya Muhammadiyah, PERSIS, Jamaah Salafi, MTA dan Jamaah Tabligh. Sedangkan Muslim kultural adalah kelompok Muslim yang memandang budaya sebagai sarana berlangsungnya transformasi agama. Bagi sebagian masyarakat Muslim di Jawa, ajaran Islam telah menjadi bagian dari budaya mereka. Perilaku keagamaan Muslim di Jawa banyak diekspresikan melalui tradisi yang telah membudaya, selain perilaku formal agama atau ibadah. Organisasi

\footnotetext{
${ }^{1}$ Tim Balai Penelitian Agama dan Kemasyarakatan Balai Litbang Jakarta, "Mencari Solusi Konflik dan Kekerasan Internal Umat Beragama," Laporan Penelitian, 2003.
} 
keagamaan yang bercorak kultural misalnya NU. Muslim kultural sebagian adalah nahdliyyin (anggota NU) dan sebagian lagi adalah para pengikut Islam Kejawen yang pada umumnya tidak memiliki organisasi keagamaan formal. ${ }^{2}$

Nahdlatul Ulama dan Muhammadiyah merupakan dua organisasi terbesar yang ada di Indonesia. Pengaruh dari kedua organisasi ini amat terasa di tengah masyarakat, meski berbeda massanya. Dakwah bi al-lisān maupun bi al-hăl yang menjadi ciri khas kedua ormas keagamaan ini sudah sejak lahirnya diketahui masyarakat, bukan saja di dalam negeri, tetapi juga di luar negeri. Sebagai organisasi terbesar di Indonesia, ternyata antara NU dan Muhammadiyah memiliki beberapa perbedaan mendasar, baik dalam teologi, visi politik maupun perbedaan yang bersifat umum, dalam hal ini perbedaan sumber daya dan infrastruktur yang kemudian berpengaruh pada jalannya kedua organisasi tersebut kurang berimbang.

Perbedaan-perbedaan yang ada mengakibatkan antara NU dan Muhammadiyah memiliki jarak mencolok, yang menjadikan kedua organisasi ini jurang pemisahnya terlalu lebar. Persaingan (kalau boleh disebut demikian) NU dan Muhammadiyah di kalangan masyarakat tidak jarang masih menyentuh hal-hal yang sebenarnya tidak terlalu penting untuk dipersoalkan seperti masalah qunut, bilangan rakaat shalat tarawih, perbedaan penetapan awal puasa atau hari raya, dan seterusnya. Di luar itu, ada pula kelompokkelompok tertentu yang begitu gampang menjustifikasi bahwa pemahamanpemahaman keagamaan yang diamalkan masyarakat sebagai bid'ah, sesat, syirik, bahkan kafir. Akibatnya, tidak produktifnya bagi perkembangan wacana kebangsaan maupun wacana keagamaan. ${ }^{3}$

Terlepas dari NU dan Muhammadiyah, akhir-akhir juga nampak potensi konflik antara NU dengan Majelis Tafsir Al-Qur'an (MTA) yang berpusat di Surakarta. MTA adalah sebuah lembaga pendidikan dan dakwah Islamiyah yang berkedudukan di Surakarta. MTA didirikan oleh Almarhum Ustadz Abdullah Thufail Saputra di Surakarta pada tangal 19 September 1972 dengan tujuan untuk mengajak umat Islam kembali ke al-Qur'an. ${ }^{4}$

Saat ini MTA sedang dipersoalkan oleh Jamaah NU di Surakarta karena menurut warga $\mathrm{NU}$ materi dan metode dakwahnya dinilai provokatif dan

\footnotetext{
${ }^{2}$ Koentjaraningrat, Kebudayaan Jawa, (Jakarta: Balai Pustaka, 1984), h.310

${ }^{3}$ Koran Tempo, Kamis, 9 Maret 2006

${ }^{4}$ http://mta-online.com/v2/sekilas-profil/ diunduh tanggal 15 juli 2012.
} 
kurang menghargai perbedaan fiqhiyyah serta cenderung melecehkan amalan yang sebagian besar dilakukan oleh warga Nahdliyin. ${ }^{5}$ Selain di Surakartasebagai pusat MTA, penyikapan warga Nahdliyin terhadap MTA nampak di beberapa daerah, seperti di Purworejo ${ }^{6}$, Kudus Jawa Tengah ${ }^{7}$, serta di Ponorogo Jawa Timur ${ }^{8}$, dan lain-lain.

Penyikapan warga Nahdliyin terhadap MTA di beberapa daerah tersebut menunjukkan potensi konflik mungkin bisa berkobar setiap saat. Mengingat pihak keamanan atau pemerintah belum terbukti kuat mengantisipasi terjadinya konflik terbuka (kekerasan massa) di balik pertentangan keyakinan. Kasus berdarah Pandeglang dan Temanggung adalah fakta yang bisa kita saksikan. Kalau dilihat dari sisi kandungan dakwah yang dikembangkan MTA, serta motede dakwahnya yang tersalur langsung melalui perangkat modern (Radio, Televisi dan Internet) sekaligus ditopang oleh infrastruktur yang kuat. Potensi lahirnya konflik terbuka sangat memungkinkan terjadi. Karena secara tidak langsung posisi MTA berseberangan dengan paham dan tradisi yang selama ini dipegang kuat oleh warga NU serta kelompok masyarakat abangan dalam istilah Clifford Geertz. Seperti penolakan terhadap kepercayaan akan benda-benda yang dianggap keramat semacam keris dan jimat. Bahkan menurut isu yang bekembang, MTA telah meminta jamaahnya yang memiliki benda-benda tersebut untuk membakarnya.

Warga NU dan kelompok abangan di Indonesia teridentifikasi sebagai kelompok masyarakat yang cukup kuat membela keyakinan tradisinya. Serta jumlahnya sangat besar. Meski di kalangan anak-anak mudanya NU sudah banyak yang berfikir moderat, toleran dan pluralis, tidak ada jaminan masyarakat NU di lapis bawah untuk tidak bergerak keras dan terlibat konflik terbuka. Begitu juga dengan kelompok masyarakat abangan yang jumlahnya banyak bersebaran di Yogyakarta dan Solo. Mereka memiliki kesadaran merawat tradisi tanpa kompromi. Sementara sepak terjang MTA semakin kuat. Sehingga potensi konfliknya bisa cukup parah.

Berbagai gambaran riil tersebut menunjukkan bahwa merajut tali kerukunan dan toleransi di tengah pluralitas agama memang bukan perkara

\footnotetext{
${ }^{5}$ Suara Merdeka, 01 April 2011.

${ }^{6}$ Fathor Rahman MD, "Waspadai Api di balikKasus MTA”, Suara Merdeka, 01 Pebruari 2011.

${ }^{7}$ Lensalndonesia.Com, "Konflik NU dan MTA".

${ }^{8}$ UmmatOnline.Net, "Warga Nahdliyin Protes, Radio MTA Ponorogo Dinilai Ajarkan Paham Wahabi," Thursday, September 29, 2011.
} 
mudah. Beberapa faktor berikut jelas merupakan ancaman bagi tercapainya toleransi. Pertama, sikap agresif para pemeluk agama dalam mendakwahkan agamanya. Kedua, adanya organisasi-organisasi keagamaan yang cenderung berorientasi pada peningkatan jumlah anggota secara kuantitatif ketimbang melakukan perbaikan kualitas keimanan para pemeluknya. Ketiga, disparitas ekonomi antar para penganut agama yang berbeda. ${ }^{9}$ Guna meminimalisir ancaman seperti ini (terutama ancaman pertama dan kedua), maka mau tidak mau umat Islam dituntut untuk menata aktivitas penyebaran atau dakwah agama secara lebih proporsional dan dewasa.

Selain itu menurut Alo Liliweri bahwa salah satu pemicu terjadinya konflik antar dan intern umat beragama adalah karena umat agama atau kelompok agama tertentu tidak dapat memahami secara benar tentang umat agama atau kelompok agama yang lain, yang memiliki latar belakang ideologi yang berbeda; yang hal itu mempengaruhi cara berfikir, bersikap, dan bertindak yang berbeda pula dengan dirinya. Karena ketidakpahamanitulah, maka banyak diantara umat beragama yang tidak tahu bagaimana seharusnya hidup dalam masyarakat yang majemuk, dengan multi agama, multietnik dan multikultur. Akibatnya hubungan antar umat beragama sering diwarnai dengan konflik, yang diakibatkan oleh adanya prasangka antar dan intern umat beragama. ${ }^{10}$

Dengan latar belakang problematika sebagaimana tersebut itulah, maka penelitian ini dilakukan. Melalui penelitian tentang prasangka ini diharapkan sekat-sekat psikologis yang selama ini menghambat arus komunikasi intern umat Islam dapat lebih terbuka. Hal inilah yang mendasari penulis, mengapa penelitian ini penting untuk dilakukan.

\section{B. Teori tentang Prasangka}

\section{Pengertian Prasangka}

Definisi klasik tentang prasangka pertama kali diperkenalkan oleh psikolog dari Universitas Harvard, Gordon Allport, dalam bukunya The Nature of

\footnotetext{
${ }^{9}$ Jajat Burhanuddin dan Arif Subhan, (ed.), Sistem Siaga Dini terhadap Kerusuhan Sosial (Jakarta: Balitbang Agama Depag RI dan PPIM, 2000), h. 28.

${ }^{10}$ Alo Liliweri, Prasangka dan Konflik: Komunikasi Lintas Budaya Masyarakat Multikultur, (Yogyakarta: LKiS, 2005), h. ix.
} 
Prejudice in 1954. Istilah itu berasal dari kata praejudicium, yang berarti: pernyataan atau kesimpulan tentang sesuatu berdasarkan perasaan atau pengalaman yang dangkal terhadap seseorang atau sekelompok orang tertentu.Lebih lanjut Allport mengemukakan bahwa "Prasangka adalah antipati berdasarkan generalisasi yang salah atau generalisasi yang tidak luwes. Antipati itu dapat dirasakan atau dinyatakan. Antipati dapat langsung ditujukan kepada kelompok atau individu dari kelompok tertentu". Kata kunci dari definisi Allport adalah "antipati", yang oleh Websters Dictionary disebut sebagai "perasaan negatif". Allport juga sangat menekankan bahwa antipati bukan hanya antipati pribadi tetapi juga antipati kelompok.

Demikian juga menurut Jones, bahwa prasangka adalah sikap antipati yang berlandaskan pada cara menggeneralisasi yang salah dan tidak fleksibel. Kesalahan itu mungkin saja diungkapkan secara langsung kepada orang yang menjadi anggota kelompok tertentu. Prasangka merupakan sikap negatif yang diarahkan kepada seseorang atas dasar perbandingan dengan kelompoknya sendiri. Menurut Effendy ${ }^{11}$ sebagaimana dikutip Liliweri, bahwa prasangka merupakan salah satu rintangan atau hambatan berat bagi kegiatan komunikasi, karena orang yang berprasangka belum apa-apa sudah bersikap curiga dan menentang komunikator yang melancarkan komunikasi. Dalam prasangka, emosi memaksa kita untuk menarik kesimpulan atas dasar syakwa sangka, tanpa menggunakan pikiran dan pandangan kita terhadap fakta yang nyata. Karena itu, sekali prasangka sudah mencekam, orang tidak akan dapat berfikir objektif dan segala apa yang dilihatnya selalu akan dinilai secara negatif.

Menurut Johnson ${ }^{12}$, bahwa prasangka antar ras dan antar etnik, meski didasarkan pada generalisasi yang keliru pada perasaan, tetapi munculnya prasangka disebabkan oleh hal tertentu, seperti (1) gambaran perbedaan antar kelompok, (2) nilai-nilai budaya yang dimiliki kelompok mayoritas sangat menguasai kelompok minoritas, (3) stereotip antar etnik, dan (4) kelompok etnik ada yang merasa superior, sehingga menjadikan etnik lain inferior.

\footnotetext{
${ }^{11}$ Onong Uchjana Effendy, Pengantar Ilmu Komunikasi, (Bandung: Alumni, 1981).

${ }^{12}$ Allan G. Johnson, Human Arrangements: an Introduction to Sociology, (Sandigeo: Harcourt Brace Jovanovich Publishing, 1986).
} 
Dalam perspektif psikologi sosial, terjadinya aksi kekerasan, permusuhan, dan ketidakadilan dalam masyarakat berasal dari adanya antagonisme kelompok. Menurut Taylor $\mathrm{dkk}^{13}$ antagonisme kelompok tampak ketika anggota satu kelompok (in group) menunjukkan sikap negatif dan perilaku negatif terhadap anggota kelompok lain (out group). Antagonisme kelompok memiliki tiga komponen yang saling terkait yaitu stereotip (stereotype), prasangka (prejudice), dan diskriminasi (discrimination). Prasangka merupakan salah satu aspek paling destruktif dari perilaku manusia dan sering menimbulkan tindakan yang mengerikan. ${ }^{14}$

Prasangka (prejudice) adalah sebuah sikap (biasanya bersifat negatif) yang ditujukan bagi anggota-anggota beberapa kelompok, yang didasarkan pada keanggotaannya dalam kelompok ${ }^{15}$ Menurut Sears ${ }^{16}$ prasangka didefinisikan sebagai persepsi orang tentang seseorang atau kelompok lain, dan sikap serta perilakunya terhadap mereka. Newcom, dkk. ${ }^{17}$ mendefinisikan prasangka adalah sikap yang tidak baik dan dapat dianggap sebagai suatu predisposisi untuk mempersepsi, berfikir, merasa dan bertindak dengan caracara yang "menentang" atau "mendekati" orang-orang lain, terutama sebagai anggota-anggota kelompok. Sedangkan menurut Brown ${ }^{18}$ prasangka adalah dipegangnya sikap sosial atau keyakinan kognitif yang bersifat merendahkan, pengekpresian afek negatif, atau tindakan permusuhan atau diskriminatif terhadap anggota suatu kelompok yang dihubungkan dengan keanggotaannya dalam kelompok tersebut.

Beberapa definisi prasangka yang dikemukakan oleh para ahli tersebut nampaknya ada beberapa kesamaan yaitu bahwa prasangka merupakan sebuah sikap sosial yang biasanya bersifat negatif, objek prasangka adalah orang atau kelompok lain, sikap tersebut didasarkan pada keanggotaan pada suatu kelompok. Berdasarkan beberapa kesamaan dalam definisi tersebut dapat diambil suatu rumusan bahwa prasangka merupakan suatu sikap sosial

\footnotetext{
${ }^{13}$ Shelley E. Taylor, dkk., Psikologi Sosial (terj.), (Jakarta: Kencana, 2009), h. 210.

${ }^{14}$ Ibid., h. 209.

${ }^{15}$ Sarwono S.W. dan Meinarno E.A. (ed.), Psikologi Sosial, (Jakarta: Salemba Humanika, 2009), h. 226.

${ }^{16}$ Sears D. O., Psikologi Sosial, Jilid II (terj.), (Jakarta: Erlangga, 1994), h. 146.

${ }^{17}$ Newcomb T.M., Psikologi Sosial, (Bandung: Diponegoro, 1985), h. 564.

${ }^{18}$ Brown R., Prejudice: Menangani Prasangka dari Perspektif Psikologi Sosial, (Yogyakarta: Pustaka Pelajar, 2005), h. 12.
} 
seseorang atau kelompok terhadap orang atau kelompok lain berupa penilaian negatif yang didasarkan pada keanggotaannya pada sustu kelompok sehingga seringkali tidak sesuai dengan kenyataan sesungguhnya.

Bentuk prasangka dapat terwujud dalam: pertama, stereotip, yaitu pemberian sifat tertentu terhadap seseorang berdasarkan kategori yang bersifat subjektif, hanya karena berasal dari kelompok out group-nya. Kedua, Jarak sosial, yaitu perasaan untuk memisahkan seseorang atau kelompok tertentu berdasarkan pada tingkat penerimaan tertentu, seperti: (1) ketidaksediaan untuk menikah dengan etnik lain, (2) ketidakmauan menjadikan etnik lain dalam anggota klubnya, (3) ketidakmauan menerima sebagai tetangga, (4) ketidakmauan menerima sebagai rekan sejabatan, (5) ketidakmauan menerima sebagai warga negaranya, (6) ketidakmauan menerima sebagai pengunjung negaranya, (7) tidak ingin menerima di negaranya. ${ }^{19}$

\section{Ciri-ciri Prasangka}

Sebagai fenomena sikap, prasangka terdiri dari tiga domain, yaitu kognitif (cognitive), afektif (affective), dan konatif (conative). Tiga domain sikap tersebut saling terkait erat, sehingga apabila diketahui kognisi (pikiran) dan afeksi (perasaan) seseorang terhadap suatu objek maka akan dapat diketahui pula konatif (kecenderungan perilakunya). Meskipun dalam kenyataan, sikap tidak selalu melahirkan perilaku (behavior) yang sesuai dengan sikap yang sebenarnya. Adanya ketidaksesuaian antara sikap dan perilaku disebabkan oleh banyak faktor lain yang mempengaruhi perilaku. ${ }^{20}$

Dalam definisi prasangka yang dikemukakan Brown ${ }^{21}$ terdapat beberapa ciri prasangka, yaitu: (1) keyakinan kognitif yang bersifat merendahkan, (2) pengekpresian perasaan negatif, (3) tindakan permusuhan, dan 4) tindakan diskriminatif. Ciri-ciri prasangka yang dikemukanan Brown tersebut telah menacakup 3 (tiga) domain prasangka, yaitu keyakinan yang bersifat merendahkan merupakan domain kognitif, perasaan negatif merupakan domain afektif, sedangkan tindakan permusuhan dan diskriminasi merupakan domain konatif yang menurut penulis masih berupa kecenderungan untuk bertindak. Dalam penelitian ini, ciri-ciri prasangka menggunakan pendapat Brown

\footnotetext{
${ }^{19}$ Alo Liliweri, Prasangka dan Konflik..., h. 199-216.

${ }^{20}$ Sarwono S.W. dan Meinarno E.A. (ed.), Psikologi Sosial..., h. 234.

${ }^{21}$ Brown R., Prejudice: Menangani..., h. 12.
} 
tersebut karena sejalan dengan pengertian prasangka sebagai sebuah sikap yang mencakup tiga domain, baik domain kognitif, afektif dan konatif.

\section{Target Prasangka}

Kajian psikologi sosial tentang target prasangka biasanya dikaitkan dengan jenis prasangka. Pembagian jenis prasangka didasrkan pada target yang menjadi sasaran prasangka. Ada beberapa target prasangka yang telah diidentifikasi dalam penelitian psikologi sosial, diantaranya sebagaimana menurut Susetyo adalah: ${ }^{22}$

1. Ras dan Etnis. Prasangka rasial adalah yang ditujukan pada kelompok ras atau etnis tertentu. Seperti etnis Cina oleh warga pribumi di Indonesia.

2. Jenis Kelamin. Prasangka jenis kelamin biasanya ditujukan kepada kaum perempuan. Misalnya perempuan tidak boleh mengemudi di Arab Saudi, perempuan tidak boleh bekerja di Afganistan, perempuan tidak boleh keluar negeri tanpa ijin suami di Sudan.

3. Homoseksual. Prasangka terhadap homoseksual seperti kaum gay dan lesbian. Prasangka terhadap homoseksual terjadi karena peran priawanita tradisional yang didominasi oleh kaum heteroseksual.

4. Agama. Prasangka yang ditujukan pada pemeluk agama tertentu banyak terjadi di berbagai Negara. Prasangka agama ini sering menimbulkan konflik berkepanjangan. Sedangkan target prasangka agama juga tidak hanya kepada pemeluk agama lain saja, tetapi juga kepada sesama agama yang memiliki pemahaman atau organisasi keagamaan yang berbeda. Sebagai contoh misalnya prasangka agama yang terjadi di kalangan kelompok Muslim, antara lain antara Muslim tradisional dan modern, antara Muslim moderat dan Muslim liberal, antara Muslim kultural dan Muslim puritan ${ }^{23}$

\section{Mengendalikan dan Mengurangi Prasangka}

Sebagai sebuah fenomena sosial, prasangka senantiasa ada terutama dalam relasi sosial antar kelompok. Namun sebenarnya prasangka merupakan problem sosial yang memiliki dampak signifikan pada relasi antar

\footnotetext{
${ }^{22}$ Susetyo, D.P.B., Stereotip dan Relasi Antar Kelompok, (Yogyakarta: Graha Ilmu, 2010), h. 75-77.

${ }^{23}$ Said Agil Sirajd, “Menyikapi Kegarangan Puritanisme," Jawa Pos, 5 April 2011.
} 
kelompok karena sifatnya yang seringkali negatif. Dalam realitas sosial, prasangka sangat tidak mungkin bisa dihapus sama sekali. Upaya yang mungkin bisa dilakukan adalah mengendalikan dan mengurangi prasangka itu sendiri. Menurut Baron dan Byrne (2003) dalam Sarwono dan Meinarno ada beberapa teknik yang dapat digunakan untuk mengendalikan prasangka yaitu: ${ }^{24}$ (a) Belajar untuk tidak membenci, (b) Meningkatkan intensitas kontak antar kelompok. (c) Rekategorisasi, yaitu melakukan perubahan batas antara ingroup dan outgroup-nya. Dengan kata lain, tidak ada lagi "us (kami) dan they (mereka)" tetapi berubah menjadi "we (kita)".

\section{Teori tentang Konflik}

\section{Pengertian Konflik}

Menurut Alo Liliweri, bahwa yang disebut konflik adalah:

a. Bentuk pertentangan alamiah yang dihasilkan oleh individu atau kelompok, karena mereka yang terlibat memiliki perbedaan sikap, kepercayaan, nilai dan kebutuhan.

b. Hubungan pertentangan antara dua pihak atau lebih (individu atau kelompok) yang memiliki, atau merasa memiliki, sasaran-sasaran tertentu namun diliputi pemikiran, perasaan atau perbuatan yang tidak sejalan.

c. Pertentangan atau pertikaian karena ada perbeedaan dalam kebutuhan, nilai, motivasi pelaku atau yang terlibat di dalamnya.

d. Suatu proses yang terjadi ketika satu pihak secara negatif mempengaruhi pihak lain, dengan melakukan kekerasan fisik yang membuat orang lain, perasaan dan fisiknya terganggu.

e. Bentuk pertentangan bersifat fungsional, karena pertentangannya mendukung tujuan kelompok dan memperbarui tampilan, namun juga disfungsional karena menghilangkan tampilan kelompok.

f. Proses mendapatkan akan monopoli ganjaran, kekuasaan, kepemilikan dengan menyingkirkan dan melemahkan para pesaing.

g. Suatu bentuk perlawanan yang melibatkan dua pihak secara antagonis.

\footnotetext{
${ }^{24}$ Sarwono S.W. dan Meinarno E.A. (ed.), Psikologi Sosial..., h. 238-239.
} 
Dari beberapa pengertian tersebut, maka dalam setiap konflik terdapat beberapa unsur yaitu:

a. Ada dua pihak atau lebih yang terlibat. Jadi ada interaksi diantara mereka.

b. Ada tujuan yang dijadikan sasaran. Tujuan itulah yang menjadi sumber konflik.

c. Ada beberapa pikiran, perasaan, tindakan diantara pihak yang terlibat untuk mendapatkan atau mencapai tujuan/sasaran.

d. Ada situasi konflik antara kedua belah pihak yang bertentangan. Ini meliputi situasi antar pribadi, antar kelompok, dan antar organisasi. $^{25}$

\section{Sumber Penyebab Konflik}

Secara umum penyebab konflik, adalah:

a. Konflik yang bersumber dari nilai, yakni perbedaan rasa percaya, keyakinan, dan ideologi.

b. Konflik yang bersumber karena kurang komunikasi.

c. Konflik yang bersumber dari pengambilan keputusan yang tidak adil.

d. Konflik yang bersumber karena ketidakcocokan peran dalam organisasi.

e. Konflik yang bersumber dari perbedaan keuntungan.

f. Konflik yang bersumber dari perubahan keseimbangan, baik karena alam atau mutasi/rotasi dan promosi dalam berorganisasi.

g. Konflik yang belum terpecahkan, sehingga seperti api dalam sekam, yang setiap waktu dapat membara. ${ }^{26}$

\section{Penyelesaian Konflik}

Secara umum untuk menyelesaikan konflik, dikenal beberapa istilah:

a. Pencegahan Konflik, bertujuan mencegah timbulnya kekerasan dalam konflik.

\footnotetext{
${ }^{25}$ Alo Liliweri, Prasangka dan Konflik...., h. 250.

${ }^{26}$ Ibid. h. 261-263.
} 
b. Penyelesaian Konflik, bertujuan mengakhiri kekerasan melalui persetujuan perdamaian.

c. Pengelolaan Konflik, bertujuan membatasi atau menghindari kekerasan melalui atau mendorong perubahan pihak-pihak yang terlibat agar berperilaku positif.

d. Resolusi Konflik, bertujuan menangani sebab-sebab konflik dan berusaha membangun hubungan baru yang relatif dapat bertahan lama diantara kelompok-kelompok yang bermusuhan.

e. Transformasi Konflik, bertujuan mengatasi sumber-sumber koflik sosial dan politik yang lebih luas dengan mengalihkan kekuatan negatif dari sumber perbedaan ke kekuatan positif. ${ }^{27}$

\section{Prasangka dan Konflik}

Antara konflik dan prasangka mempunyai hubungan yang erat. Prasangka masih mengandung sikap, pikiran, keyakinan, kepercayaan yang negatif terhadap kelompok tertentu. Dari prasangka inilah akan memunculkan tindakan diskriminasi. Jika prasangka masih berada di pikiran, tetapi diskriminasi sudah mengarah ke tindakan sistematis. Diskriminasi akan memunculkan tindakan yang berusaha menyingkirkan status dan peran sekelompok orang dari hubungan, pergaulan, serta komunikasi antar manusia. Dari tindakan diskriminasi inilah lama-kelamaan tentu akan memunculkan konflik.

Prasangka menurut Rose, (dalam Gerungan, 1981) dapat merugikan masyarakat secara dan umum dan organisasi khususnya. Hal ini terjadi karena prasangka dapat menghambat perkembangan potensi individu secara maksimal. Selanjutnya Steplan et.al, (1978) menguraikan bahwa prasangka tidak saja mempengaruhi perilaku orang dewasa tetapi juga anak-anak sehingga dapat membatasi kesempatan mereka berkembang menjadi orang yang memiliki toleransi terhadap kelompok sasaran misalnya kelompok minoritas.

Rosenbreg dan Simmons, (1971) juga menguraikan bahwa prasangka akan menjadikan kelompok individu tertentu dengan kelompok individu lain berbeda kedudukannya, dan menjadikan mereka tidak mau bergabung atau

\footnotetext{
${ }^{27}$ Ibid. h. 287-288.
} 
bersosialisasi. Apabila hal ini terjadi dalam masyarakat tentu akan merusak kerjasama. Kesimpulan yang dapat diambil dari uraian tentang dampak prasangka di atas adalah bahwa dengan adanya prasangka akan mempengaruhi sikap dan tingkah laku seseorang dalam berbagai situasi. Prasangka dapat menjadikan seseorang atau kelompok tertentu tidak mau bergabung atau bersosialisasi dengan kelompok lain. Apabila kondisi tersebut terdapat dalam organisasi dan masyarakat akan mengganggu kejasama yang baik, sehingga upaya pencapaian tujuan organisasi kurang dapat terealisir dengan baik.

\section{E. Prasangka dan Potensi Konflik Antara Jamaah Nahdlatul Ulama (NU) dan Majelis Tafsir AI-Qur'an (MTA) di Surakarta}

Menurut Elizabeth bahwa dalam masyarakat Indonesia yang multi etnik, suku bangsa dan kesukubangsaan adalah sebuah kenyataan yang ada dalam kehidupan sehari-hari. Anggota masyarakat dilahirkan, dan dididik dalam suasana askriptif-primordial kesukubangsaan. Dalam suasana askriptif kesukubangsaan itulah, perbedaan antara siapa "saya" dan siapa "dia/kamu", dan antara siapa "kami" dan siapa "mereka" jelas batas-batasnya, dan selalu diulang dan dipertegas, diproduksi dan direproduksi secara budaya. Dalam ruang lingkup batas-batas kesukubangsaan itu stereotype dan prasangka (prejudice) berkembang dan menjadi mantap dalam suatu kurun waktu hubungan antarsuku bangsa yang tidak terbatas. ${ }^{28}$ Akibatnya hubungan antar etnik, antar kelompok, antar pemeluk agama sering diwarnai oleh prasangka sosial dalam bentuk sikap, stereotip, jarak sosial, diskriminasi, dan kompetisi yang tidak sehat, yang ujung-unjungnya sering menimbulkan konflik.

Secara khusus terkait konflik antar dan intern pemeluk agama, menurut Alo Liliweri bahwa salah satu pemicu terjadinya konflik dan intern umat beragama adalah karena umat agama atau kelompok agama tertentu tidak dapat memahami secara benar tentang umat agama atau kelompok agama yang lain, yang memiliki latar belakang ideologi yang berbeda; yang hal itu mempengaruhi cara berfikir, bersikap, dan bertindak yang berbeda pula dengan

\footnotetext{
${ }^{28}$ Misbah Zulfa Elizabeth, "Multi Etnisitas Indonesia dan Potensi Konflik di dalamnya”, dalam Musahadi HAM (Ed.), Mediasi dan Resolusi Konflikdi Indonesia: Dari Konflik Agama hingga Mediasi Peradilan, Semarang: WMC IAIN Walisongo, 2007), h. xii.
} 
dirinya. Karena ketidakpahaman itulah, maka banyak diantara umat beragama yang tidak tahu bagaimana seharusnya hidup dalam masyarakat yang majemuk, dengan multi agama, multietnik dan multikultur. Akibatnya hubungan antar umat beragama sering diwarnai dengan konflik, yang diakibatkan oleh adanya prasangka antar dan intern umat beragama. ${ }^{29}$

Agama Islam barangkali merupakan agama yang paling banyak mengalami konflik internal. Sejak masa awal, sepeninggal Nabi Muhammad SAW, konflik dan kekerasan hampir tidak pernah mereda dan menjadi fenomena kesejarahan, serta berlangsung dalam seluruh kurun waktu peradaban. Kepentingan kelompok umat Islam yang dilatarbelakangi oleh ambisi kekuasaan dan perbedaan faham ikut tumbuh dan berkembang, serta dapat memicu terjadinya konflik internal umat Islam. ${ }^{30}$

Dalam kontek masyarakat Muslim, khususnya di Jawa, ada dua kelompok Muslim yang diantara keduanya seringkali terjadi ketegangan, baik dalam bentuk konflik terbuka maupun yang bersifat laten. Kelompok Muslim tersebut adalah kelompok Muslim puritan dan kelompok Muslim cultural. Muslim puritan adalah kelompok Muslim yang menganut faham puritanisme Islam, yaitu suatu faham yang berusaha untuk memurnikan ajaran Islam dari pengaruh luar (termasuk budaya) baik dalam bentuk keyakinan, pemikiran maupun praktik keagamaan. Organisasi yang bercorak puritan misalnya Muhammadiyah, Persatuan Islam (PERSIS), Jamaah Salafi, Majelis Tafsir AlQur'an (MTA) dan Jamaah Tabligh. Sedangkan Muslim cultural adalah kelompok Muslim yang memandang budaya sebagai sarana berlangsungnya transformasi agama. Bagi sebagian masyarakat Muslim di Jawa, ajaran Islam telah menjadi bagian dari budaya mereka. Perilaku keagamaan Muslim di Jawa banyak diekspresikan melalui tradisi yang telah membudaya, selain perilaku formal agama atau ibadah. Organisasi keagamaan yang bercorak kultural misalnya Nahdlatul Ulama (NU). Muslim kultural sebagian adalah Nahdliyyin (anggota NU) dan sebagian lagi adalah para pengikut Islam Kejawen yang pada umumnya tidak memiliki organisasi keagamaan formal. ${ }^{31}$

\footnotetext{
${ }^{29}$ Alo Liliweri, Prasangka dan Konflik..., h. ix.

30 Tim Balai Penelitian Agama dan Kemasyarakatan Balai Litbang Jakarta, "Mencari Solusi Konflik dan Kekerasan Internal Umat Beragama”, Laporan Penelitian, 2003.

${ }^{31}$ Koentjaraningrat, Kebudayaan Jawa, (Jakarta: Balai Pustaka, 1984), h. 310.
} 
Akhir-akhir juga nampak potensi konflik antara jamaah NU dengan MTA yang berpusat di Surakarta. MTA dipersoalkan oleh Jamaah NU karena menurut warga NU materi dan metode dakwahnya dinilai provokatif dan kurang menghargai perbedaan fiqhiyah serta cenderung melecehkan amalan-amalan yang sebagian besar dilakukan oleh warga Nahdliyin. ${ }^{32}$

Hal ini diperkuat oleh Mibtadin, dalam penelitiannya tentang "Gerakan Keagamaan Kontemporer (Studi Analisis Potensi Konflik Sosial Keagamaan Dari Perkembangan Majlis Tafsir Al-Qur'an/MTA di Surakarta)." ${ }^{33}$ Hasil dari penelitian ini adalah bahwa secara umum beberapa ajaran MTA yang memiliki potensi konflik sosial di masyarakat adalah sebagai berikut: Pertama, Islam dan persoalan tradisi lokal. Dalam pandangan MTA orang yang beragama secara murni adalah orang yang beragama Islam tanpa mencampur agama dengan tradisi yang berlaku di masyarakat. Amalan seperti tingkeban, selapanan, slametan, ziarah kubur dengan menabur bunga adalah perbuatan bid'ah yang diancam neraka. Kedua, persolan ibadah yang tidak diajarkan oleh Islam seperti dzikir bersama, tahlilan, membaca manāqib, dan membaca al-Barzanji serta shalawatan. Bagi mereka yang mengadakannya berarti sesat, sebab tidak ada tuntunannya dalam al-Qur'an dan al-Sunnah. Ketiga, persoalan klaim kebenaran. Hal ini berkaitan dengan cara MTA menyebarkan ajarannya yang sangat mudah menuduh komunitas yang lain sesat, bid'ah dan keliru. Klaim kebenaran ini juga diikuti sikap yang eklusif dengan mengedepankan keunggulan kelompok. Misalnya dalam hal pernikahan para pemimpin MTA menganjurkan lebih utama menikah dengan sesama warga MTA.

Sedangkan potensi konflik yang bersumber dari prasangka antara Jamaah NU dan MTA di Surakarta, sebagaimana fokus penelitian ini, juga masih terlihat ada. Hal ini tercermin dari beberapa tanggapan terkait dengan prasangka diantara keduanya.

Untuk melihat bagaimana tinggi rendahnya prasangka antara Jamaah NU dengan MTA, maka terlebih dahulu penulis sampaikan skala kriteriumnya, yaitu:

32 Suara Merdeka, 01 April 2011.

33 Mibtadin, "Gerakan Keagamaan Kontemporer (Studi Analisis Potensi Konflik Sosial Keagamaan Dari Perkembangan Majlis Tafsir Al-Qur'an/MTA di Surkarta)," Laporan Penelitian, (Semarang: Balai Litbang Agama Semarang, 2010). 
Kriterium Nilai Prasangka

\begin{tabular}{ccl}
\hline No. & Score Rata-rata & \multicolumn{1}{c}{ Skala Kriteria } \\
\hline 1 & $1.00-1,80$ & Sangat Rendah \\
2 & $1,80-2,60$ & Rendah \\
3 & $2,60-3,40$ & Sedang \\
4 & $3,40-4,20$ & Tinggi \\
5 & $4,20-5,00$ & Sangat Tinggi \\
\hline
\end{tabular}

Sebelum penulis mendeskripsikan hasil penelitian dari masing-masing indikator dalam penelitian ini, terlebih dahulu penulis akan menyampaikan data mengenai latar belakang pendidikan subjek penelitian dari Jamaah NU dan MTA sebagai berikut:

Subjek Penelitian Jamaah NU berdasarkan Pendidikan

\begin{tabular}{|c|c|c|c|}
\hline No. & Pendidikan & Jumlah & Frekuensi \\
\hline 1 & $\mathrm{SD} / \mathrm{MI}$ & 3 & $3 \%$ \\
\hline 2 & SMP/ MTs & 21 & $21 \%$ \\
\hline 3 & SMA/ MA/ PGA & 32 & $32 \%$ \\
\hline 4 & Mahasiswa & 24 & $24 \%$ \\
\hline 5 & S.1 & 13 & $13 \%$ \\
\hline \multirow[t]{2}{*}{6} & S.2 & 7 & $7 \%$ \\
\hline & Jumlah & 100 & $100 \%$ \\
\hline
\end{tabular}

Subjek Penelitian Jamaah MTA berdasarkan Pendidikan

\begin{tabular}{clcc}
\hline No. & \multicolumn{1}{c}{ Pendidikan } & Jumlah & Frekuensi \\
\hline 1 & SD / MI & 0 & $0 \%$ \\
2 & SMP/ MTs & 9 & $13 \%$ \\
3 & SMA/ MA/ PGA & 43 & $62.3 \%$ \\
4 & Mahasiswa & 11 & $15.9 \%$ \\
5 & S.1 & 6 & $8.7 \%$ \\
\hline & Jumlah & $\mathbf{6 9}$ & $\mathbf{1 0 0 \%}$ \\
\hline
\end{tabular}




\section{Aspek Kognisi (Keyakinan yang Merendahkan)}

\begin{tabular}{|c|c|c|c|}
\hline \multirow{2}{*}{ No. } & \multirow{2}{*}{ Pernyataan } & \multicolumn{2}{|c|}{ Rata-rata } \\
\hline & & NU & MTA \\
\hline 1 & $\begin{array}{l}\text { Kebanyakan pengikut MTA/NU adalah } \\
\text { orang yang luas pengetahuan agamanya }\end{array}$ & 3,47 & 3,26 \\
\hline 2 & $\begin{array}{l}\text { Sebenarnya perlu juga mempelajari prinsip } \\
\text { gerakan dakwah MTA/NU untuk } \\
\text { menambah wawasan keagamaan saya }\end{array}$ & 2,74 & 2,0 \\
\hline 3 & $\begin{array}{l}\text { Aktivitas dakwah MTA/NU memiliki tujuan } \\
\text { yang sama dengan aktivitas dakwah NU, } \\
\text { karena sama-sama untuk kebaikan umat }\end{array}$ & 3,11 & 2,78 \\
\hline 4 & $\begin{array}{l}\text { Ustadz-Ustadz di MTA/NU sangat dalam } \\
\text { pengetahuan agamanya }\end{array}$ & 3,45 & 2,95 \\
\hline 5 & $\begin{array}{l}\text { Menurut pendapat saya pengikut MTA/NU } \\
\text { tidak memberi sumbangan yang sangat } \\
\text { berarti bagi kemajuan Islam }\end{array}$ & 3,41 & 2,65 \\
\hline 6 & $\begin{array}{l}\text { Pemahaman agama di kalangan anggota } \\
\text { MTA/NU menurut saya adalah pemahaman } \\
\text { yang menyimpang dari kebenaran }\end{array}$ & 3,44 & 1,87 \\
\hline 7 & $\begin{array}{l}\text { Sebagian besar ibadah orang MTA/NU } \\
\text { adalah sia-sia, karena tidak sesuai tuntunan } \\
\text { al-Qur'an dan as-Sunah }\end{array}$ & 3,01 & 3,13 \\
\hline \multirow[t]{2}{*}{8} & $\begin{array}{l}\text { MTA/NU adalah Ormas Islam yang } \\
\text { menghalalkan daging anjing/ penyebar } \\
\text { bid'ah }\end{array}$ & 3,15 & 3,48 \\
\hline & Rata-rata Total & 3,22 & 2,76 \\
\hline
\end{tabular}

Berdasarkan tabel tersebut terlihat bahwa prasangka antara jamaah NU dan MTA di Surakarta jika dilihat dari aspek kognisi (keyakinan yang merendahkan), nilai totalnya masih masuk dalam kriteria sedang, yakni prasangka jamaah NU terhadap MTA dengan nilai rata-rata 3,22, dan sebaliknya prasangka jamaah MTA terhadap NU dengan nilai rata-rata 2,76. Artinya potensi konflik akibat prasangka dari aspek kognisi ini masih tergolong rendah, walaupun jika dilihat dari nilai rata-rata masing-masing item masih ada beberapa yang masuk kriteria tinggi, seperti tanggapan jamaah NU terhadap pernyataan "Kebanyakan pengikut MTA adalah orang yang luas pengetahuan agamanya" dengan nilai rata-rata 3,47 (kriteria 
tinggi). Sebaliknya tanggapan jamaah MTA terhadap pernyataan: "Kebanyakan pengikut NU adalah orang yang luas pengetahuan agamanya" dengan nilai rata-rata 3,26 (kriteria sedang).

Demikian juga tanggapan jamaah NU terhadap pernyataan: "UstadzUstadz di MTA sangat dalam pengetahuan agamanya", nilai rata-ratanya 3,45 (kriteria tinggi), sebaliknya tanggapan jamaah MTA terhadap pernyataan: "Ustadz-Ustadz di NU sangat dalam pengetahuan agamanya", dengan nilai rata-rata 2,65 (kriteria sedang). Hal senada juga tanggapan jamaah NU terhadap pernyataan: "Pemahaman agama di kalangan anggota MTA menurut saya adalah pemahaman yang menyimpang dari kebenaran", nilai rata-ratanya 3,44 (kriteria tinggi), sebaliknya tanggapan jamaah MTA terhadap pernyataan: "Pemahaman agama di kalangan anggota NU menurut saya adalah pemahaman yang menyimpang dari kebenaran", nilai rata-ratanya 1,87 (kriteria rendah). Tingginya prasangka Jamaah MTA terhadap NU dari aspek kognisi (keyakinan yang merendahkan) terlihat dari tanggapan terhadap pernyataan: "NU adalah ormas Islam yang menyebarkan bid'ah", dengan nilai rata-rata 3,48 (kriteria tinggi). Hal inilah yang memang sering dikeluhkan jamaah NU terhadap gerakan dakwah MTA. Saat ini Majelis Tafsir Al-Qur'an (MTA) sedang dipersoalkan oleh Jamaah Nahdlatul Ulama karena menurut warga NU materi dan metode dakwahnya dinilai provokatif dan kurang menghargai perbedaan fiqhiyah serta cenderung melecehkan amalan-amalan yang sebagian besar dilakukan oleh warga Nahdliyin. ${ }^{34}$

Sebaliknya tanggapan jamaah NU terhadap pernyataan: "MTA adalah ormas Islam yang menghalalkan daging anjing", dengan nilai rata-rata 3,15 (kriteria sedang). Walaupun dalam persoalan ini dijawab oleh pimpinan MTA "Ustadz Ahmad Sukino" di video yang diunggah di website MTA, dengan judul "Pelurusan Berita Bohong". Menurutnya MTA tidak pernah menyampaikan tentang kehalalan daging anjing sebagaimana berita yang sementara ini beredar. Karena menurutnya yang berhak menghalalkan dan mengharamkan sesuatu mutlak hak Allah, jadi berita yang beredar tentang MTA yang menghalalkan daging anjing adalah fitnah yang keji.

${ }^{34}$ Suara Merdeka, 01 April 2011. 


\section{Aspek Afeksi (Ekspresi Perasaan Negatif)}

\begin{tabular}{|c|c|c|c|}
\hline \multirow{2}{*}{ No. } & \multirow{2}{*}{ Pernyataan } & \multicolumn{2}{|c|}{ Rata-rata } \\
\hline & & NU & MTA \\
\hline 1 & $\begin{array}{l}\text { Saya turut bersyukur apabila para anggota } \\
\text { MTA/NU konsisten dengan keyakinannya }\end{array}$ & 3,07 & 2,52 \\
\hline 2 & $\begin{array}{l}\text { Saya turut bangga apabila kelompok } \\
\text { MTA/NU berhasil dalam dakwahnya }\end{array}$ & 3,72 & 2,35 \\
\hline 3 & $\begin{array}{l}\text { Saya sangat terkesan terhadap kesungguhan } \\
\text { anggota MTA/NU dalam mengamalkan } \\
\text { ajaran agamanya }\end{array}$ & 3,06 & 3,22 \\
\hline 4 & $\begin{array}{l}\text { Saya ikut merasa senang, jika tetangga saya } \\
\text { yang anggota MTA/NU sukses dalam } \\
\text { usahanya }\end{array}$ & 3,06 & 1,91 \\
\hline 5 & $\begin{array}{l}\text { Saya merasa tidak nyaman apabila bergaul } \\
\text { dengan orang MTA/NU }\end{array}$ & 2,99 & 2,13 \\
\hline 6 & $\begin{array}{l}\text { Saya benci apabila melihat pengikut } \\
\text { MTA/NU menonjolkan identitas } \\
\text { kelompoknya }\end{array}$ & 3,50 & 2,26 \\
\hline 7 & $\begin{array}{l}\text { Saya merasa terancam apabila anggota } \\
\text { MTA/NU memiliki pengaruh yang kuat di } \\
\text { daerah saya }\end{array}$ & 3,57 & 1,96 \\
\hline 8 & $\begin{array}{l}\text { Saya merasa tidak khusuk jika berjamaah } \\
\text { shalat dengan anggota MTA/NU }\end{array}$ & 3,25 & 2,09 \\
\hline & Rata-rata Total & 3,27 & 2,30 \\
\hline
\end{tabular}

Potensi konflik antara jamaah NU dan MTA berdasar pada prasangka yang dilihat dari aspek afeksi (ekspresi perasaan negatif) dapat dilihat dari nilai rata-rata total prasangka antar keduanya. Dari tabel tersebut terlihat bahwa nilai rata-rata afeksi (ekspresi perasaan negatif) jamaah $\mathrm{NU}$ terhadap MTA, nilai rata-rata totalnya 3,27 (kriteria sedang), dan sebaliknya afeksi (ekspresi perasaan negatif) jamaah MTA terhadap NU, nilai rata-rata totalnya 2,30 (kriteria rendah). Artinya potensi konflik akibat prasangka dari aspek afeksi (ekspresi perasaan negatif) juga masih rendah. Walaupun jika dilihat dari sebaran nilai rata-rata masing-masing item juga masih ada yang tinggi.

Hal ini terlihat dari tanggapan jamaah NU terhadap pernyataan: "Saya turut bangga apabila kelompok MTA berhasil dalam dakwahnya", nilai rata- 
ratanya 3,72 (kriteria tinggi). Artinya jamaah NU masih khawatir jika dakwah MTA berhasil. Sebaliknya jawaban jamaah MTA terhadap pernyataan: "Saya turut bangga apabila kelompok NU berhasil dalam dakwahnya", nilai rataratanya 2,35 (kriteria rendah). Artinya jamaah MTA rata-rata tidak begitu khawatir terhadap keberhasilan dakwah jamaah NU.

Tingginya prasangka jamaah NU terhadap MTA juga terlihat dari tanggapan terhadap pernyataan: "Saya benci apabila melihat pengikut MTA menonjolkan identitas kelompoknya", nilai rata-ratanya 3,50 (kriteria tinggi). Namun kebalikannya, tanggapan jamaah MTA terhadap pernyataan: "Saya benci apabila melihat pengikut NU menonjolkan identitas kelompoknya", nilai rata-ratanya hanya 2,26 (kriteria rendah).

Selanjutnya tanggapan jamaah NU terhadap pernyataan: "Saya merasa terancam apabila anggota MTA memiliki pengaruh yang kuat di daerah saya", nilai rata-ratanya 3,57 (kriteria tinggi). Sebaliknya tanggapan jamaah MTA terhadap pernyataan: "Saya merasa terancam apabila anggota NU memiliki pengaruh yang kuat di daerah saya", nilai rata-ratanya 1,96 (kriteria rendah). Artinya jamaah NU lebih khawatir jika jamaah MTA berpengaruh di daerahnya, dibandingkan kekhawatiran jamaah MTA terhadap pengaruh jamaah NU.

\section{Aspek Konasi (Keinginan Tindakan Bermusuhan)}

\begin{tabular}{|c|c|c|c|}
\hline \multirow{2}{*}{ No. } & \multirow{2}{*}{ Pernyataan } & \multicolumn{2}{|c|}{ Rata-Rata } \\
\hline & & NU & MTA \\
\hline 1 & $\begin{array}{l}\text { Saya bersedia menyediakan fasilitas untuk } \\
\text { kegiatan para anggota MTA/NU. }\end{array}$ & 4,29 & 3,65 \\
\hline 2 & $\begin{array}{l}\text { Saya akan membiarkan anggota MTA/NU yang } \\
\text { mengajak keluarga saya untuk mengikuti kegiatan } \\
\text { kelompoknya. }\end{array}$ & 4,44 & 4,26 \\
\hline 3 & $\begin{array}{l}\text { Saya bersedia bekerjasama dengan anggota } \\
\text { MTA/NU untuk memperoleh manfaat bagi kedua } \\
\text { belah pihak. }\end{array}$ & 3,13 & 2,52 \\
\hline 4 & $\begin{array}{l}\text { Saya tidak akan menghalangi dan menentang, jika } \\
\text { di masjid saya dipergunakan untuk pengajian rutin } \\
\text { jamaah MTA/NU. }\end{array}$ & 3,71 & 2,60 \\
\hline 5 & $\begin{array}{l}\text { Saya akan memboikot aktivitas dakwah anggota } \\
\text { MTA/NU di kampung saya. }\end{array}$ & 3,26 & 2,04 \\
\hline 6 & $\begin{array}{l}\text { Saya akan selalu mewaspadai aktivitas dakwah } \\
\text { anggota MTA/NU pada masyarakat di sekitar saya }\end{array}$ & 3,99 & 2,65 \\
\hline
\end{tabular}




\begin{tabular}{llll}
7 & $\begin{array}{l}\text { Menurut saya antara anggota NU dan MTA } \\
\text { selamanya sulit untuk bersatu. }\end{array}$ & $\mathbf{3 , 8 5}$ & $\mathbf{2 , 9 1}$ \\
$8 \quad \begin{array}{l}\text { Saya akan membela mati-matian teman saya, } \\
\text { walaupun ia salah, ketika berperkara dengan } \\
\text { anggota MTA/NU. }\end{array}$ & $\mathbf{2 , 0 8}$ & $\mathbf{1 , 7 8}$ \\
\hline & $\mathbf{3 , 5 9}$ & $\mathbf{2 , 9 1}$ \\
\hline
\end{tabular}

Tingginya potensi konflik jika dilihat dari aspek konasi (keinginan tindakan bermusuhan) dari jamaah NU ke MTA juga terlihat dari tabel di atas, yakni nilai rata-rata totalnya 3,59 (kriteria tinggi). Sebaliknya nilai rata-rata total jamaah MTA hanya 2,91 (kriteria sedang).

Ada beberapa item yang mendukung tingginya nilai rata-rata keinginan tindakan bermusuhan, diantaranya tanggapan terhadap pernyataan: "Saya bersedia menyediakan fasilitas untuk kegiatan para anggota MTA", nilai rataratanya 4,29 (kriteria sangat tinggi). Demikian juga tanggapan jamaah MTA terhadap pernyataan: "Saya bersedia menyediakan fasilitas untuk kegiatan para anggota $\mathrm{NU}$ ", nilai rata-ratanya 3,65 (kriteria tinggi). Artinya antara jamaah NU dan MTA sama-sama tidak mau menyediakan fasilitas untuk kegiatan di luar kelompoknya (NU dan MTA).

Potensi konflik antara jamaah NU dan MTA juga terlihat dari tingginya nilai rata-rata terhadap pernyataan: "Saya akan membiarkan anggota MTA/ NU yang mengajak keluarga saya untuk mengikuti kegiatan kelompoknya". Dimana jamaah NU nilai rata-ratanya 4,44 (kriteria sangat tinggi), demikian juga nilai rata-rata jamaah MTA yakni 4,26 (kriteria sangat tinggi). Artinya antara jamaah NU atau MTA tidak rela jika anggota keluarganya diajak untuk ikut pengajian di luar kelompoknya.

Tingkat kewaspadaan yang tinggi juga ditunjukkan jamaah NU terhadap MTA, hal terlihat dari tanggapan terhadap pernyataan: "Saya akan selalu mewaspadai aktivitas dakwah anggota MTA pada masyarakat di sekitar saya", dengan nilai rat-rata 3,99 (kriteria tinggi). Artinya jamaah NU sangat waspada terhadap aktivitas dakwah MTA. Sebaliknya tanggapan MTA terhadap pernyataan: "Saya akan selalu mewaspadai aktivitas dakwah anggota NU pada masyarakat di sekitar saya", nilai rata-ratanya hanya 2,65 (kriteria sedang). 


\section{Aspek Konasi (Keinginan Tindakan Diskriminasi)}

\begin{tabular}{|c|c|c|c|}
\hline \multirow{2}{*}{ No. } & \multirow{2}{*}{ Pernyataan } & \multicolumn{2}{|c|}{ Rata-Rata } \\
\hline & & NU & MTA \\
\hline 1 & $\begin{array}{l}\text { Bagi saya tidak masalah belajar agama kepada } \\
\text { orang MTA/NU kalau memang kualitas } \\
\text { keilmuannya bagus. }\end{array}$ & 2,88 & 1,65 \\
\hline 2 & $\begin{array}{l}\text { Saya akan mendengarkan dengan penuh } \\
\text { perhatian ceramah orang MTA/NU kalau } \\
\text { memang menarik dan berbobot. }\end{array}$ & 2,70 & 2,04 \\
\hline 3 & $\begin{array}{l}\text { Sebaiknya saya mendukung aktivitas dakwah } \\
\text { MTA/NU karena sama-sama gerakan dakwah } \\
\text { Islam. }\end{array}$ & 3,62 & 2,74 \\
\hline 4 & $\begin{array}{l}\text { Saya akan memilih ketua takmir masjid yang } \\
\text { berasal dari anggota MTA/NU, kalau dia benar- } \\
\text { benar mumpuni. }\end{array}$ & 4,05 & 2,30 \\
\hline 5 & $\begin{array}{l}\text { Saya senantiasa berusaha agar orang MTA/NU } \\
\text { tidak menempati posisi penting dalam } \\
\text { masyarakat. }\end{array}$ & 3,66 & 2,17 \\
\hline 6 & $\begin{array}{l}\text { Saya keberatan jika anggota MTA/NU dijadikan } \\
\text { imam masjid di kampong saya meskipun ia fasih } \\
\text { membaca al-Qur'an }\end{array}$ & 3,17 & 2,39 \\
\hline 7 & $\begin{array}{l}\text { Saya tidak setuju jika anggota keluarga saya } \\
\text { menikah dengan anggota MTA/NU, meskipun ia } \\
\text { taat beragama. }\end{array}$ & 3,18 & 2,35 \\
\hline \multirow[t]{2}{*}{8} & $\begin{array}{l}\text { Jika saya menjadi ketua RT, saya akan membatasi } \\
\text { keterlibatan anggota jamaah MTA/NU dalam } \\
\text { setiap kegiatan di RT. }\end{array}$ & 2,91 & 1,96 \\
\hline & Rata-rata Total & 3,27 & 2,19 \\
\hline
\end{tabular}

Potensi konflik antara jamaah NU dan MTA jika dilihat dari aspek konasi (keinginan diskriminasi) juga terlihat tidak terlalu tinggi, yakni untuk jamaah NU nilai rata-rata totalnya 3,27 (kriteria sedang), dan nilai rata-rata total jamaah MTA 2,19 (kriteria rendah).

Dilihat dari sebaran rata-rata masing-masing item, ada beberapa yang menunjukkan tingginya keinginan berdiskriminasi jamaah NU terhadap MTA, diantaranya tanggapan terhadap peranyataan: "Saya akan memilih ketua takmir masjid yang berasal dari anggota MTA, kalau dia benar-benar 
mumpuni", nilai rata-ratanya 4,05 (kriteria tinggi). Artinya jamaah NU mayoritas tidak akan memilih orang MTA sebagai ketua takmir masjid, walaupun dia benar-benar mumpuni. Sebaliknya mayoritas orang MTA masih mau memilih orang NU sebagai ketua takmir masjid, kalau dia benarbenar mumpuni, yakni dengan nilai-rata 2,30 (kriteria rendah).

Demikian juga terlihat dari tanggapan jamaah NU terhadap pernyataan: "Saya senantiasa berusaha agar orang MTA tidak menempati posisi penting dalam masyarakat", nilai rata-ratanya 3,66 (kriteria tinggi), sebaliknya tanggapan MTA hanya bernilai rata-rata 2,17 (kriteria rendah). Artinya masih ada keinginan yang tinggi dari jamaah $\mathrm{NU}$ untuk berusaha menghalangi jamaah MTA untuk menduduki posisi penting di masyarakat. Sebaliknya tidak begitu dengan jamaah MTA.

Dari beberapa data tersebut di atas menunjukkan masih adanya potensi konflik antara jamaah NU dan MTA di Surakarta jika dilihat dari prasangka antara keduanya. Walaupun jika dilihat dari nilai rata-rata totalnya, potensi konfliknya masih rendah. Namun ada beberapa item yang menunjukkan bahwa prasangka jamaah NU terhadap MTA begitu tinggi. Hal ini akan sangat punya potensi konflik yang tinggi, jika diimbangi pula oleh tingginya prasangka jamaah MTA terhadap NU.

Dengan adanya prasangka yang berpotensi menimbulkan konflik tersebut maka harus diantisipasi oleh pengurus kedua organisasi massa Islam di Surakarta ini. Karena sebagaimana disampaikan H. Hilmy Sa'dullah (Ketua PCNU Surakarta), bahwa sekarang ini warga Nahdlatul Ulama "wes panas kupinge", bahkan "wes panas atine" karena mendengarkan materi dan melihat pola dakwahnya MTA, yang dirasa oleh warga NU melecehkan ideologi dan keyakinannya. Menurutnya, ibaratkan telur ditaruh di atas kepala akan "mateng" sendiri. ${ }^{35}$

Banyak warga NU yang berasal dari luar Surakarta menghubunginya untuk "nggruduk" MTA ke kota Surakarta, namun niat itu diredamnya dengan memberikan pengertian. Walaupun demikian masih banyak respon yang muncul dari warga Nahdhiyin menyikapi metode dan dakwah MTA dengan berbagai macam bentuk. Seperti munculnya gerakan dakwah Jamaah Muji

${ }^{35}$ Wawancara, Ahad, 5 Juli 2012. 
Rasul dan Ahbabul Musthofa, yang tetap ingin melestarikan tradisi-tradisi warga Nahdliyin. Dalam setiap kegiatan yang diselenggarakan Jamuro dan Ahbabul Musthofa, selalu dihadiri jamaah puluhan ribu orang.

Tidak hanya itu, di Solo Raya sekarang juga berdiri radio-radio baru yang berafiliasi dengan faham Nahdliyin, seperti Radio Al-Hidayah FM di Pasar Kliwon Solo, Radio Gesma FM di Pondok Pesantren Al-Muayyad Solo, Radio Bani Adam FM di Boyolali dan Radio As-Sunah FM di Pondok Pesantren Sukorejo Andong Boyolali. Kesemuanya itu berdiri sebagai respon terhadap keberadaan Radio MTA FM, yang sekarang berubah menjadi Radio Persada FM.

Respon lain juga diperlihatkan dalam beberapa kegiatan ke NU-an yang diselenggarakan di Kota Surakarta, diantaranya Puncak peringatan Hari Lahir (Harlah) pengurus Pusat Gerakan Pemuda Ansor yang digelar di stadion Manahan Solo, Senin, 16 Juli 2012 yang dihadiri 40 ribu lebih anggota Ansor se-Jawa Tengah dan sebagian Jawa Timur ikut ambil bagian menghadirinya. Sebelumnya juga digelar parade Hadroh dengan berjalan kaki dari Lapangan Kota Barat menuju Balai Kota di Surakarta, yang diikuti ratusan Group Rebana.

\section{F. Kesimpulan}

Dari hasil penelitian yang berjudul "Prasangka Potensi Pemicu Konflik Internal Umat Islam (Studi Antara Jamaah Nadlatul Ulama dan Majelis Tafsir Al-Qur'an di Surakarta), maka dapat disimpulkan:

1. Prasangka Jamaah NU terhadap Jamaah MTAdi Surakarta, jika dilihat dari aspek kognisi (keyakinan yang merendahkan), afeksi (ekspresi perasaan negatif) dan konasi (keinginan tindakan bermusuhan dan diskriminasi total nilai ratanya 3,34 (kriteria sedang), dengan rentang kriterium terendah 1,0 dan tertingi 5,0.

b. Prasangka Jamaah MTA terhadap Jamaah NU di Surakarta, jika dilihat dari aspek kognisi (keyakinan yang merendahkan), afeksi (ekspresi perasaan negatif) dan konasi (keinginan tindakan bermusuhan dan diksriminasi total nilai ratanya 2,54 (kriteria rendah), dengan rentang kriterium terendah 1,0 dan tertingi 5,0.

c. Potensi konflik antara NU dengan Jamaah MTA di Surakarta jika dilihat dari prasangka keduanya memang masih ada, tetapi tidak begitu tinggi. 
Walaupun jika dilihat dari prasangka dari Jamaah NU terhadap Jamaah MTA di Surakarta masuk kriterium sedang, namun potensi konflik ini bisa rendah karena prasangka Jamaah MTA terhadap Jamaah NU di Surakarta nilainya rendah. [w] 


\section{BIBLIOGRAFI}

Abdul Djamil, "Pluralisme Agama di Indonesia", makalah, disampaikan dalam Silaturrahim Tokoh-tokoh Agama, MUI Jawa Tengah, 2003.

Achmad N., Pluralitas Agama: Kerukunan dalam Keragaman, Jakarta: Penerbit Buku Kompas, 2001.

Adian Husaini, Solusi Damai Islam-Kristen, Surabaya: Pustaka Progresif, 2003.

Allan G. Johnson, Human Arrangements: an Introduction to Sociology,. Sandigeo: Harcourt Brace Jovanovich Publishing, 1986.

Alo Liliweri, Prasangka dan Konflik: Komunikasi Lintas Budaya Masyarakat Multikultur, Yogyakarta: LKIS, 2005.

Balitbang Depag, Konflik Sosial Bernuansa Agama di Indonesia, Jakarta: Departemen Agama RI, 2003.

Brown R., Prejudice: Menangani Prasangka dari Perspektif Psikologi Sosial, Yogyakarta: Pustaka Pelajar, 2005

Choirul Mahfud, Pendidikan Multikultural, Yogyakarta: Pustaka Pelajar, 2008.

Dewi Fortuna Anwar, dkk. (ed.), Konflik Kekerasan Internal: Tinjauan Sejarah, Ekonomi-Politik, dan Kebijakan di Asia Pasifik, Jakarta: Yayasan Obor Indonesia, Most-LIPI, LASEMA-CNRS, KITLV, 2005.

Fathor Rahman MD, "Waspadai Api di balik Kasus MTA”, dalam Suara Merdeka, 1 Pebruari 2011.

Hikam M., A.S., Islam, Demokratisasi dan Pemberdayaan Civil Society, Jakarta: Erlangga, 2000.

Jajat Burhanuddin dan Arif Subhan, eds., Sistem Siaga Dini terhadap Kerusuhan Sosial, Jakarta: Balitbang Agama Depag RI dan PPIM, 2000.

Koentjaraningrat, Kebudayaan Jawa, Jakarta: Balai Pustaka, 1984.

LensaIndonesia.Com, "Konflik NU dan MTA."

M. Alfandi, Sikap, "Prasangka, dan Diskriminasi Potensi Pemicu Konflik Antara Etnis Jawa dan Cina (Tionghoa)", Laporan Penelitian, Semarang: Puslit IAIN Walisongo, 2007. 
MUI Jawa Tengah, Peta Dakwah Jawa Tengah Tahun 2004.

Musahadi (ed.), Mediasi dan Resolusi Konflik di Indonesia: dari Konflik Agama hingga Mediasi Peradilan, Semarang: Walisongo Mediation Center, 2007.

Newcomb T.M., Psikologi Sosial, Bandung: Diponegoro, 1985.

Nottingham E.K., Agama dan Masyarakat: Suatu Pengantar Sosiologi Agama, Jakarta: Rajawali Pers, 1997.

Nurkholis Madjid, Islam Kemodernan dan Keindonesiaan, Bandung: Mizan, 1994.

O'dea T.F,, Sosiologi Agama, (terj.), Jakarta: Rajawali, 1990.

Onong Uchjana Effendy, Pengantar Ilmu Komunikasi, Bandung: Alumni, 1981.

Peter Worsley etal, Pengantar Sosiologi: Sebuah Pembanding (terj.), Yogyakarta: Tiara Wacana, 1992.

Rosnow, Ralph L., Poultry and Prejudice. Psychology Today, March, 1972

Said Agil Sirajd, Menyikapi Kegarangan Puritanisme, Jawa Pos, 5 April 2011.

Sarwono S.W. dan Meinarno E.A. (ed.), Psikologi Sosial, Jakarta: Salemba Humanika, 2009.

Sears D. O., Psikologi Sosial Jilid II (terj.), Jakarta: Erlangga, 1994.

Shelley E. Taylor, dkk, Psikologi Sosial (terj.), Jakarta: Kencana, 2009.

Sjafri Sairin, Perubahan Sosial Masyarakat Indonesia: Perpektif Antropologi, Yogyakarta: Pustaka Pelajar, 2002.

Soerjono Soekanto, Sosiologi Suatu Pengantar, Jakarta: Raja Grafindo Persada, 1990.

Stephen K. Sanderson, Makro Sosiologi: Sebuah Pendekatan Terhadap Realitas Sosial, (terj.), Jakarta: Raja Grafindo Persada, 2000.

Sugiyono dan Eri Wibowo, Statistika Penelitian dan Aplikasinya dengan SPSS 10.0 for Windows, Bandung: Alfabeta, 2001.

Sugiyono, Metode Penelitian Administrasi, Bandung: Alfabeta, 1999.

Sugiyono, Metode Penelitian Bisnis, Bandung: Alfabeta, 1999.

Susetyo, D.P.B., Stereotip dan Relasi Antar Kelompok, Yogyakarta: Graha Ilmu, 2010.

Sutrisno Hadi, Metodologi Research, Jilid 1, 2 Yogyakarta: UGM, 1986.

Syamsir, Potensi Konflik Sosial Berbasisi Agama di Minangkabau, Flamma Analisis, 2010. 
Thouless R.H., Psikologi Agama, (terj.), Jakarta: Rajawali, 1992.

Tim Balai Penelitian Agama dan Kemasyarakatan Balai Litbang Jakarta, "Mencari Solusi Konflik dan Kekerasan Internal Umat Beragama," Laporan Penelitian, 2003.

\section{Internet dan Surat Kabar:}

http://mta-online.com/v2/sekilas-profil/

http://UmmatOnline.Net, "Warga Nahdliyin Protes, Radio MTA Ponorogo Dinilai Ajarkan Paham Wahabi," Thursday, September 29, 2011.

Koran Tempo, Kamis, 9 Maret 2006.

Suara Merdeka, 1 April 2011. 